\title{
Evaluation of Soil Health and Soil Quality Analysis of Different Blocks of Bundi District, Rajasthan, India
}

\author{
Banwari Lal Meena*, Tarence Thomas and Narendra Swaroop
}

Department of Soil Science and Agricultural Chemistry, Naini Agricultural Institute, Sam Higginbottom University of Agriculture, Technology and Sciences, Prayagraj-211007, U.P., India

*Corresponding author

\section{A B S T R A C T}

\section{Keywords}

Soil health, Soil quality, Chemical properties, Bundi, Soil, etc

Article Info

Accepted:

20 July 2020

Available Online:

10 August 2020
One of the most popular phrase in agriculture is the term "Soil Health". The health of soil determines agricultural sustainability. Soil quality assessment is of paramount importance to know the appropriate management practices to be adopted for sustainable crop production. In this study, all soil chemical properties and available macronutrients status with their spatial variability in different blocks of Bundi district in Rajasthan was conducted. It is concluded that soil reaction was neutral to slightly alkaline with EC mostly below $<1.0 \mathrm{dS} \mathrm{m}{ }^{-1}$ which are favourable for crop production. The organic carbon, nitrogen and phosphorus content of these soils were found to be low to medium. Potassium was in high range. Calcium and magnesium were found to be adequate. The available sulphur in soil was recorded in medium range. Soil health and soil quality were found to be affected by the management practices adopted by the farmers and the degree of manure and fertilizer usage over a period of time. We concluded that there is a need of proper nutrition and management approaches for sustenance of soil health and soil quality which optimize the multiple functions of soil, conserve soil resources, support strategies for promoting soil health and soil quality are important. The use of organic manure for fertilization management can be recommended as a means for promoting soil health and soil quality.

\section{Introduction}

"Dokuchaev defined soil as an independent natural body developed over time under the influence of five soil-forming factors: parent rock, living organisms, climate, relief and time" (Dokuchaev, 1948). "Soil is more or less a loose and crumby part of the outer earth crust in which, by means of their roots, plants may or do find foot hold and nourishment as well as other conditions essential to their growth" (Hilgard, 1892).
Agriculture is one of the world's most important activities supporting human life. Potential land use assessment is likely to the prediction of land potential for productive land use type (Dadhwal et al., 2011). Land productivity capacity or land quality is a comprehension, at the same time a precise concept in terms of agricultural activities (Dengiz and Saglam, 2012). Agricultural intensification and massive infrastructure development in the recent years without considering the variability of entire 
production system enhances the risk of soil erosion and fertility depletion (Singh et al., 2007). Soil is a component of the lithosphere and biosphere system. It is a vast natural resource on which the life supporting systems and socio-economic development depends. Organic matter is one of the most important constituents of soil, a good amount of organic carbon / matter in soil increase soil fertility. The core constraints in relation to land use include depletion of organic carbon, soil micronutrients and macronutrients, removal of top soil by erosion, change of physical properties and increased soil salinity (Kumar et al., 2017).

Geographically, Rajasthan is located between $23^{\circ} 3^{\prime}$ to $30^{\circ} 12^{\prime}$ North latitude and $69^{\circ} 30^{\prime}$ to $78^{\circ} 17^{\prime}$ East longitude, with the tropic of cancer passing through the southernmost tip of the state. The climate of Rajasthan plain is characterized by extremely high range of temperature and aridity although sharing the monsoonal variations throughout the year it is the hottest region of India (mean June temperature $34.5 \mathrm{C}$ at Jaisalmer and Bikaner) with annual range of temperature between 14 to $17{ }^{\circ} \mathrm{C}$. The rainfall is very low, highly erratic and variable seasonally. Average rainfall of Rajasthan is $52.26 \mathrm{~cm}$ with high degree of regional and temporal variability. The climate of Rajasthan state has varied contrasts and the presence of Aravallis is the greatest influencing factor. The state can broadly be divided into Arid, Semi-Arid and Sub-Humid Regions, on the basis of rainfall intensities. The Western Rajasthan i.e. in the arid region consist of the districts of Hanumangarh, Jaisalmer, Barmer, Ganganagar, Churu, Jhunjhunu, Sikar, Nagaur, Jodhpur, Pali and Jalore covering an area of nearly $1,43,842$ square kilometres. The region is characterized by low and highly variable rainfall years creating inhospitable living condition to both human and livestock population. An area of 9,290 square kilometres in extreme western parts of the state has true desert conditions. With an improvement in rainfall pattern from the west towards the east Rajasthan semi-arid conditions are created in area of about 66,830 square kilometres in the districts of Alwar, Jaipur, Bharatpur, Ajmer, Tonk, Sawai Madhopur, Bhilwara, Bundi, Kota, Chittorgarh, Udaipur, Sirohi, Dungarpur and parts of Jhalawar and Banswara.

The soils of the Bundi district can be broadly classified as the Deep Brown Loamy, Deep Brown Clayey, Medium Brown Loamy, Shallow Yellowish Brown Gravelly Loamy, Deep Black Clayey and Red Gravelly Loam Hilly soils. Under the new system, most soils of Rajasthanbelong to only 5 ordersAridisols, Alfisols, Entisols, Inceptisols and Vertisols (District Profile, KVK). Bundi is a district of Rajasthan. Bundi is located between $25^{\circ} 25^{\prime} 57.3132^{\prime \prime} \mathrm{N}$ and $75^{\circ} 38^{\prime} 53.7828^{\prime \prime}$ E. It has an average elevation of 268 meters (879 feet) from sea level. The district has an area of 5,550 square kilometres. The climate of the district is extremely hot in the summers and fairly cold in the winters. The average annual temperature is $26.5^{\circ} \mathrm{C}$ in Bundi. The average annual rainfall of the region is 772 mm (District Factbook, 2019).

The term "soil health" originates in the observation that soil quality influences the health of animals and humans via the quality of crops (Warkentin, 1995). "Soil health, also referred to as soil quality, is defined as the continued capacity of soil to function as a vital living ecosystem that sustains plants, animals and humans." According to MoebiusClune et al., (2016) a conceptual difference between the two terms may be that soil quality comprises both inherent and dynamic properties, whereas soil health is focused on the dynamic properties. The term "soil fertility" is often used as a synonym to the term "soil quality". Indeed, the definition of 
Mader et al., (2002) that a fertile soil "provides essential nutrients for crop plant growth, supports a diverse and active biotic community, exhibits a typical soil structure, and allows for an undisturbed decomposition" went beyond the provision of yields. In line with this, the maintenance of "natural soil fertility" is at the heart of organic farming (Rusch, 1985). The concept of soil quality as introduced by Larson and Pierce (1991) and Doran and Parkin (1994) was heavily criticized in a series of papers (Letey et al., 2003; Sojka \& Upchurch, 1999; Sojka et al., 2003) for being subjective and ill-defined.

A particular recommendation was to speak of soil use rather than soil functions, so that the responsibility to maintain the quality of the soil can be clearly assigned to the user of the soil. In particular, it was claimed to raise awareness and enhance communication between various stakeholders regarding the importance of soil resources (Karlen et al., 2001).

According to USDA soil quality indicators are classified into four categories that include visual, physical, chemical and biological indicators. The physical indicators are related to the organization of the particles and pores, reflecting effects on root growth, speed of plant emergence and water infiltration; they include depth, bulk density, porosity, aggregate stability, texture and compaction. Chemical indicators include $\mathrm{pH}$, salinity, organic matter content, phosphorus availability, cation exchange capacity, nutrient cycling and the presence of contaminants such as heavy metals, organic compounds, radioactive substances, etc.

These indicators determine the presence of soil-plant-related organisms, nutrient availability, water for plants and other organisms and mobility of contaminants. Finally, biological indicators include measurements of micro and macro-organisms, their activities or functions. Concentration or population of earthworms, nematodes, termites, ants, as well as microbial biomass, fungi, actinomycetes, or lichens can be used as indicators, because of their role in soil development and conservation; nutrient cycling and specific soil fertility (Anderson, 2003). Biological indicators also include metabolic processes such as respiration, used to measure microbial activity related to decomposition of organic matter in soil (Bastida et al., 2008).

\section{Materials and Methods}

The present study entitled "Evaluation of Soil Health and Soil Quality Analysis of Different Blocks of Bundi District, Rajasthan, India" was conducted during the 2019-20 in three stages i.e. soil survey and mapping, collection of samples and their analysis for different soil parameters.

\section{Site details}

Bundi district is the south-east region of Rajasthan, from where the soil has been taken for analysis. Bundi is located between $25^{\circ} 25^{\prime} 57.3132 " \mathrm{~N}$ and $75^{\circ} 38^{\prime} 53.7828^{\prime \prime}$ E. It has an average elevation of 268 meters (879 feet) from sea level. The district has an area of 5,550 square kilometres. The climate of the district is extremely hot in the summers and fairly cold in the winters.

The average annual temperature is $26.5^{\circ} \mathrm{C}$ in Bundi. The average annual rainfall of the region is $772 \mathrm{~mm}$ (District Factbook, 2019).The soils of the Bundi district can be broadly classified as the Deep Brown Loamy, Deep Brown Clayey, Medium Brown Loamy, Shallow Yellowish Brown Gravelly Loamy, Deep Black Clayey and Red Gravelly Loam Hilly soils (District Profile, KVK). 


\section{Soil Sampling}

Soil samples were collected from the three different blocks of Bundi district Rajasthan. They are Nainwan, Karwar and Indergarh. Soil samples were collected with the help of Khurpi, Spade and meter scale. In each block three village selected for sampling and samples obtained from two different depths 0 $15 \mathrm{~cm}$ and $15-30 \mathrm{~cm}$, totally eighteen soil sample were collected.

\section{Results and Discussion}

\section{Soil reaction}

In soil depth the highest mean $\mathrm{pH}$ was found in $15-30 \mathrm{~cm}$ (7.41) which is significantly higher than $0-15 \mathrm{~cm}$ (7.28). In villages the maximum mean $\mathrm{pH}$ was found at $\operatorname{Mani}\left(\mathrm{V}_{5}\right)$ (7.75) and minimum mean $\mathrm{pH}$ was found in Gambhira $\left(\mathrm{V}_{2}\right)$ (6.99) (Table 1).

The increase in $\mathrm{pH}$ with depth of soil is possibly due to leaching down of salts from upper soil depth to lower soil depth, which is accumulation of salts in lower depth of soil and increase in soil $\mathrm{pH}$. Similar results were reported by Mehta et al.(2012), Maheshwari and Sharma (2013) and Gill et al., (2012).

\section{Electrical conductivity}

In soil depth the highest mean EC was found in $15-30 \mathrm{~cm} \quad\left(0.63 \mathrm{dS} \mathrm{m}^{-1}\right)$ which is significantly higher than $0-15 \mathrm{~cm}^{\left(0.59 \mathrm{dS} \mathrm{m}^{-}\right.}$ $\left.{ }^{1}\right)$.In villages the maximum mean $\mathrm{EC}$ was found at Ramajpura $\left(\mathrm{V}_{8}\right)\left(1.01 \mathrm{dS} \mathrm{m}{ }^{-1}\right)$ and minimum mean $\mathrm{EC}$ was found in Babai $\left(\mathrm{V}_{9}\right)$ $\left(0.21 \mathrm{dS} \mathrm{m}^{-1}\right)$.

The low EC may be due to good drainage conditions which favoured the removal of released bases by percolating and drainage water. Similar results were reported by Ram et al., (2010) (Table 2).

\section{Organic carbon}

In soil depth the highest mean organic carbon was found in $0-15 \mathrm{~cm}(0.56 \%)$ which is significantly higher than $15-30 \mathrm{~cm}(0.41 \%)$. In villages the maximum mean organic carbon was found at Mani $\left(\mathrm{V}_{5}\right)(0.68 \%)$ and minimum mean organic carbon was found in Jainiwas $\left(\mathrm{V}_{7}\right)(0.36 \%)$. The organic carbon content of these soils was found to be low to medium and ranging from 0.36 to $0.68 \%$. The organic carbon content decreased with depth and this is due to the addition of plant residues and farmyard manure to surface horizons than in the lower horizons. Similar results were reported by Maheshwari and Sharma (2013) and Gill et al., (2012) (Table 3).

\section{Organic matter}

In soil depth the highest mean organic matter was found in $0-15 \mathrm{~cm}(0.96 \%)$ which is significantly higher than $15-30 \mathrm{~cm}(0.70 \%)$. In villages the maximum mean organic matter was found at Mani $\left(\mathrm{V}_{5}\right)(1.16 \%)$ and minimum mean organic matter was found in Jainiwas $\left(\mathrm{V}_{7}\right)(0.62 \%)$. The organic matter \% decreases abruptly with increase in soil depth. Similar results were reported by Kumar et al., (2014).

\section{Available nitrogen}

In soil depth the highest mean available nitrogen was found in $0-15 \mathrm{~cm}\left(273.72 \mathrm{~kg} \mathrm{ha}^{-}\right.$ $\left.{ }^{1}\right)$ which is significantly higher than $15-30 \mathrm{~cm}$ (251.94 $\left.\mathrm{kg} \mathrm{ha}^{-1}\right)$. In villages the maximum mean available nitrogen was found at Mani $\left(\mathrm{V}_{5}\right)\left(301.2 \mathrm{~kg} \mathrm{ha}^{-1}\right)$ and minimum mean available nitrogen was found in Jainiwas $\left(\mathrm{V}_{7}\right)$ $\left(192.19 \mathrm{~kg} \mathrm{ha}^{-1}\right)$. The available nitrogen decreases abruptly with increase in soil depth. However, available $\mathrm{N}$ content found to be maximum in surface horizons and decreased regularly with depth which is due to 
decreasing trend of organic carbon with depth and cultivation of crops are mainly confined to the surface horizon (Rhizosphere) only at regular interval the depleted nitrogen content is supplemented by the external addition of fertilizers during crop cultivation. Similar results were reported by Urmila et al. (2018).

Table.1 Soil chemical properties and their respective methods for analysis

\begin{tabular}{|c|l|l|l|l|}
\hline S. No. & Parameters & Unit & Methodology & Author's \\
\hline 1. & Soil $\mathrm{pH}(1: 2)$ & - & Digital $\mathrm{pH}$ Meter & Jackson, 1958 \\
\hline 2. & $\begin{array}{l}\text { Electrical conductivity } \\
(1: 2)\end{array}$ & $\mathrm{dS} \mathrm{m}{ }^{-1}$ & $\begin{array}{l}\text { DigitalConductivity } \\
\text { Meter }\end{array}$ & Wilcox, 1950 \\
\hline 3. & Organic carbon & $\%$ & Rapid titration & Walkley, 1947 \\
\hline 4. & Organic matter & $\%$ & $\%$ OM $=\%$ OC $\times 1.724$ & Van Bemmelen Factor \\
\hline 5. & Available nitrogen & $\mathrm{kg} \mathrm{ha}^{-1}$ & $\begin{array}{l}\text { Alkaline potassium } \\
\text { permanganate }\end{array}$ & Subbiah and Asija, 1956 \\
\hline 6. & Available phosphorus & $\mathrm{kg} \mathrm{ha}^{-1}$ & Spectrophotometric & Olsen et al., 1954 \\
\hline 7. & Available potassium & $\mathrm{kg} \mathrm{ha}^{-1}$ & Flame Photometric & Toth and Prince, 1949 \\
\hline 8. & $\begin{array}{l}\text { Exchangeable calciumand } \\
\text { magnesium }\end{array}$ & $\left.\mathrm{Cmol}^{+} \mathrm{p}^{+}\right) \mathrm{kg}^{-1}$ & $\begin{array}{l}\text { 1NNeutral ammonium } \\
\text { acetate saturation /EDTA }\end{array}$ & Cheng and Bray, 1951 \\
\hline 9. & Available Sulphur & $\mathrm{ppm}$ & Turbidimetric & Chesnin and Yien, 1950 \\
\hline
\end{tabular}

Table. 2 Chemical properties of soil of different villages of Bundi district, Rajasthan

\begin{tabular}{|c|c|c|c|c|c|c|c|c|}
\hline \multirow[t]{2}{*}{ Villages } & \multicolumn{4}{|c|}{ Soil pH } & \multicolumn{4}{|c|}{ Soil EC $\left(\mathrm{dS} \mathrm{m}^{-1}\right)$} \\
\hline & $0-15 \mathrm{~cm}$ & \multicolumn{2}{|c|}{$15-30 \mathrm{~cm}$} & Mean & $0-15 \mathrm{~cm}$ & \multicolumn{2}{|c|}{$15-30 \mathrm{~cm}$} & Mean \\
\hline $\begin{array}{l}\text { Kashpuriya } \\
\left(\mathbf{V}_{1}\right)\end{array}$ & 7.50 & 7.52 & & 7.51 & 0.64 & 0.70 & & 0.67 \\
\hline Gambhira $\left(V_{2}\right)$ & 6.75 & 7.23 & & 6.99 & 0.91 & 0.96 & & 0.94 \\
\hline $\operatorname{Manpura}\left(V_{3}\right)$ & 7.39 & 7.43 & & 7.41 & 0.50 & 0.55 & & 0.53 \\
\hline $\operatorname{Karwar}\left(\mathbf{V}_{4}\right)$ & 7.08 & 7.16 & & 7.12 & 0.51 & 0.54 & & 0.53 \\
\hline $\operatorname{Mani}\left(V_{5}\right)$ & 7.66 & 7.83 & & 7.75 & 0.23 & 0.29 & & 0.26 \\
\hline Kashipura $\left(\mathbf{V}_{6}\right)$ & 6.92 & 7.20 & & 7.06 & 0.50 & 0.57 & & 0.54 \\
\hline Jainiwas $\left(\mathbf{V}_{7}\right)$ & 7.46 & 7.55 & & 7.51 & 0.80 & 0.83 & & 0.82 \\
\hline $\begin{array}{l}\text { Ramajpura } \\
\left(\mathbf{V}_{\mathbf{8}}\right)\end{array}$ & 7.41 & 7.42 & & 7.42 & 1.00 & 1.02 & & 1.01 \\
\hline Babai $\left(\mathbf{V}_{\mathbf{9}}\right)$ & 7.38 & 7.39 & & 7.39 & 0.18 & 0.24 & & 0.21 \\
\hline \multirow[t]{2}{*}{ Mean } & 7.28 & 7.41 & & & 0.59 & 0.63 & & \\
\hline & F-test & S.Ed $( \pm)$ & C.I & at $0.05 \%$ & F-test & S.Ed $( \pm)$ & C.D & D. at $0.05 \%$ \\
\hline Due to depth & $\mathrm{S}$ & 0.09 & 0.0 & & $\mathrm{~S}$ & 0.03 & & 0003 \\
\hline Due to site & S & 0.25 & 0.0 & & S & 0.28 & 0.00 & 0000000003 \\
\hline
\end{tabular}


Table.3 Chemical properties of soil of different villages of Bundi district, Rajasthan

\begin{tabular}{|c|c|c|c|c|c|c|c|c|}
\hline \multirow[t]{2}{*}{ Villages } & \multicolumn{4}{|c|}{ Organic carbon $(\%)$} & \multicolumn{4}{|c|}{ Organic matter (\%) } \\
\hline & $0-15 \mathrm{~cm}$ & \multicolumn{2}{|c|}{$15-30 \mathrm{~cm}$} & Mean & $0-15 \mathrm{~cm}$ & \multicolumn{2}{|c|}{$15-30 \mathrm{~cm}$} & Mean \\
\hline $\begin{array}{l}\text { Kashpuriya } \\
\left(V_{1}\right)\end{array}$ & 0.52 & \multicolumn{2}{|l|}{0.35} & 0.44 & 0.90 & \multicolumn{2}{|c|}{0.60} & 0.75 \\
\hline Gambhira $\left(\mathbf{V}_{2}\right)$ & 0.63 & \multicolumn{2}{|l|}{0.42} & 0.53 & 1.09 & \multicolumn{2}{|l|}{0.72} & 0.91 \\
\hline $\operatorname{Manpura}\left(\mathbf{V}_{3}\right)$ & 0.56 & \multicolumn{2}{|l|}{0.37} & 0.47 & 0.97 & \multicolumn{2}{|l|}{0.64} & 0.81 \\
\hline $\operatorname{Karwar}\left(\mathbf{V}_{4}\right)$ & 0.69 & \multicolumn{2}{|l|}{0.55} & 0.62 & 1.19 & \multicolumn{2}{|l|}{0.95} & 1.07 \\
\hline $\operatorname{Mani}\left(V_{5}\right)$ & 0.75 & \multicolumn{2}{|l|}{0.6} & 0.68 & 1.29 & \multicolumn{2}{|l|}{1.03} & 1.16 \\
\hline Kashipura $\left(\mathbf{V}_{6}\right)$ & 0.6 & \multicolumn{2}{|l|}{0.45} & 0.53 & 1.03 & \multicolumn{2}{|l|}{0.78} & 0.91 \\
\hline Jainiwas $\left(\mathbf{V}_{7}\right)$ & 0.41 & \multicolumn{2}{|l|}{0.31} & 0.36 & 0.71 & \multicolumn{2}{|l|}{0.53} & 0.62 \\
\hline $\begin{array}{l}\text { Ramajpura } \\
\left(\mathbf{V}_{8}\right)\end{array}$ & 0.42 & \multicolumn{2}{|l|}{0.32} & 0.37 & 0.72 & \multicolumn{2}{|l|}{0.55} & 0.64 \\
\hline Babai $\left(V_{9}\right)$ & 0.45 & \multicolumn{2}{|l|}{0.3} & 0.38 & 0.78 & \multicolumn{2}{|l|}{0.52} & 0.65 \\
\hline \multirow[t]{2}{*}{ Mean } & 0.56 & \multicolumn{2}{|l|}{0.41} & & 0.96 & \multicolumn{2}{|l|}{0.70} & \\
\hline & F-test & $\operatorname{S.Ed}( \pm)$ & $\begin{array}{l}\text { C.D } \\
\%\end{array}$ & at 0.05 & F-test & S.Ed $( \pm)$ & C.I & . at $0.05 \%$ \\
\hline Due to depth & $\mathrm{S}$ & 0.11 & 0.0 & 0002 & $\mathrm{~S}$ & 0.19 & 0.0 & 00002 \\
\hline Due to site & $\mathrm{S}$ & 0.11 & 0.0 & 001 & $\mathrm{~S}$ & 0.19 & 0.0 & 0002 \\
\hline
\end{tabular}

Table.4 Chemical properties of soil of different villages of Bundi district, Rajasthan

\begin{tabular}{|c|c|c|c|c|c|c|c|}
\hline \multirow[t]{2}{*}{ Villages } & \multicolumn{4}{|c|}{ Available nitrogen $\left(\mathrm{kg} \mathrm{ha}^{-1}\right)$} & \multicolumn{3}{|c|}{ Available phosphorus (kg ha $\left.{ }^{-1}\right)$} \\
\hline & $0-15 \mathrm{~cm}$ & \multicolumn{2}{|c|}{$15-30 \mathrm{~cm}$} & Mean & $0-15 \mathrm{~cm}$ & $15-30 \mathrm{~cm}$ & Mean \\
\hline $\begin{array}{l}\text { Kashpuriya } \\
\left(\mathbf{V}_{1}\right)\end{array}$ & 291.3 & 281.2 & & 286.25 & 12.09 & 11.23 & 11.66 \\
\hline Gambhira $\left(V_{2}\right)$ & 297.4 & 283.6 & & 290.5 & 14.98 & 12.80 & 13.89 \\
\hline $\operatorname{Manpura}\left(\mathbf{V}_{3}\right)$ & 294.3 & 282.24 & & 288.27 & 11.23 & 10.47 & 10.85 \\
\hline Karwar $\left(\mathbf{V}_{4}\right)$ & 309.7 & 287.1 & & 298.4 & 11.86 & 10.21 & 11.04 \\
\hline $\operatorname{Mani}\left(V_{5}\right)$ & 313.6 & 288.8 & & 301.2 & 11.26 & 9.96 & 10.61 \\
\hline Kashipura $\left(\mathbf{V}_{6}\right)$ & 306.4 & 286.7 & & 296.55 & 10.38 & 10.19 & 10.29 \\
\hline Jainiwas $\left(\mathbf{V}_{7}\right)$ & 207.13 & 177.24 & & 192.19 & 11.45 & 10.46 & 10.96 \\
\hline $\begin{array}{l}\text { Ramajpura } \\
\left(\mathbf{V}_{8}\right)\end{array}$ & 219.52 & 188.16 & & 203.84 & 11.47 & 11.33 & 11.4 \\
\hline Babai (V9) & 224.17 & 192.4 & & 208.29 & 10.85 & 10.82 & 10.84 \\
\hline \multirow[t]{2}{*}{ Mean } & 273.72 & 251.94 & & & 11.73 & 10.83 & \\
\hline & F-test & $\operatorname{S.Ed}( \pm)$ & C.D & at $0.05 \%$ & F-test & S.Ed $( \pm)$ & C.D. at $0.05 \%$ \\
\hline Due to depth & $\mathrm{S}$ & 15.41 & 0.0 & 05 & $\mathrm{~S}$ & 0.64 & 0.006 \\
\hline Due to site & $\mathrm{S}$ & 46.48 & 0.0 & 0002 & $\mathrm{~S}$ & 1.06 & 0.003 \\
\hline
\end{tabular}


Table.5 Chemical properties of soil of different villages of Bundi district, Rajasthan

\begin{tabular}{|c|c|c|c|c|c|c|c|c|}
\hline \multirow[t]{2}{*}{ Villages } & \multicolumn{4}{|c|}{ Available potassium $\left(\mathrm{kg} \mathrm{ha}^{-1}\right)$} & \multicolumn{4}{|c|}{$\begin{array}{l}\text { Exchangeable calcium } \\
\left(\mathrm{Cmol}\left(\mathbf{p}^{+}\right) \mathrm{kg}^{-1}\right)\end{array}$} \\
\hline & $0-15 \mathrm{~cm}$ & \multicolumn{2}{|c|}{$15-30 \mathrm{~cm}$} & Mean & $0-15 \mathrm{~cm}$ & \multicolumn{2}{|c|}{$15-30 \mathrm{~cm}$} & Mean \\
\hline $\begin{array}{l}\text { Kashpuriya } \\
\left(\mathbf{V}_{1}\right)\end{array}$ & 418.67 & \multicolumn{2}{|l|}{408} & 413.34 & 6.86 & \multicolumn{2}{|l|}{6.47} & 6.67 \\
\hline Gambhira $\left(\mathbf{V}_{2}\right)$ & 432 & \multicolumn{2}{|l|}{425} & 428.5 & 5.32 & \multicolumn{2}{|l|}{5.14} & 5.23 \\
\hline $\operatorname{Manpura}\left(V_{3}\right)$ & 388 & \multicolumn{2}{|l|}{375} & 381.5 & 7.56 & \multicolumn{2}{|l|}{6.97} & 7.27 \\
\hline $\operatorname{Karwar}\left(\mathbf{V}_{4}\right)$ & 736.5 & \multicolumn{2}{|l|}{722} & 729.25 & 4.02 & \multicolumn{2}{|l|}{3.07} & 3.55 \\
\hline Mani $\left(V_{5}\right)$ & 538 & \multicolumn{2}{|l|}{529} & 533.5 & 9.39 & \multicolumn{2}{|l|}{8.77} & 9.08 \\
\hline Kashipura $\left(V_{6}\right)$ & 422 & \multicolumn{2}{|l|}{415} & 418.5 & 6.03 & \multicolumn{2}{|l|}{5.67} & 5.85 \\
\hline Jainiwas $\left(\mathbf{V}_{7}\right)$ & 389 & \multicolumn{2}{|l|}{383} & 386 & 8.13 & \multicolumn{2}{|l|}{7.21} & 7.67 \\
\hline $\begin{array}{l}\text { Ramajpura } \\
\left(\mathbf{V}_{\mathbf{8}}\right)\end{array}$ & 516 & \multicolumn{2}{|l|}{511} & 513.5 & 4.17 & \multicolumn{2}{|l|}{3.87} & 4.02 \\
\hline Babai $\left(\mathbf{V}_{9}\right)$ & 326 & \multicolumn{2}{|l|}{319} & 322.5 & 5.09 & \multicolumn{2}{|l|}{5.02} & 5.06 \\
\hline \multirow[t]{2}{*}{ Mean } & 462.91 & \multicolumn{3}{|c|}{454.11} & 6.29 & \multicolumn{2}{|l|}{5.8} & \\
\hline & F-test & $\begin{array}{l}\text { S.Ed } \\
( \pm)\end{array}$ & $\begin{array}{l}\text { C.I } \\
\%\end{array}$ & t 0.05 & F-test & S.Ed $( \pm)$ & C.D & . at $0.05 \%$ \\
\hline Due to depth & $\mathrm{S}$ & 6.22 & 0.0 & 004 & $\mathrm{~S}$ & 0.34 & 0.00 & \\
\hline Due to site & $\mathrm{S}$ & 120.51 & $\begin{array}{l}0.0 \\
00 c\end{array}$ & 00000000 & $\mathrm{~S}$ & 1.79 & 0.00 & 000001 \\
\hline
\end{tabular}

Table.6 Chemical properties of soil of different villages of Bundi district, Rajasthan

\begin{tabular}{|c|c|c|c|c|c|c|c|c|}
\hline \multirow[t]{2}{*}{ Villages } & \multicolumn{4}{|c|}{$\begin{array}{l}\text { Exchangeable magnesium } \\
\left(\mathrm{Cmol}\left(\mathbf{p}^{+}\right) \mathbf{k g}^{-1}\right)\end{array}$} & \multicolumn{4}{|c|}{ Available sulphur (ppm) } \\
\hline & $0-15 \mathrm{~cm}$ & \multicolumn{2}{|c|}{$15-30 \mathrm{~cm}$} & Mean & $0-15 \mathrm{~cm}$ & \multicolumn{2}{|c|}{$15-30 \mathrm{~cm}$} & Mean \\
\hline Kashpuriya $\left(V_{1}\right)$ & 1.64 & 1.47 & & 1.56 & 14.88 & 14.27 & & 14.58 \\
\hline Gambhira $\left(\mathbf{V}_{2}\right)$ & 3.18 & 3.09 & & 3.14 & 15.45 & 15.14 & & 15.3 \\
\hline Manpura $\left(\mathbf{V}_{\mathbf{3}}\right)$ & 2.20 & 2.03 & & 2.12 & 15.03 & 15.02 & & 15.03 \\
\hline Karwar $\left(\mathbf{V}_{\mathbf{4}}\right)$ & 5.28 & 5.21 & & 5.25 & 16.67 & 16.39 & & 16.53 \\
\hline $\operatorname{Mani}\left(\mathbf{V}_{\mathbf{5}}\right)$ & 3.66 & 3.54 & & 3.6 & 17.32 & 17.19 & & 17.26 \\
\hline Kashipura $\left(V_{6}\right)$ & 3.14 & 3.06 & & 3.1 & 16.11 & 16.04 & & 16.08 \\
\hline Jainiwas $\left(\mathbf{V}_{7}\right)$ & 4.26 & 4.17 & & 4.22 & 13.55 & 13.28 & & 13.42 \\
\hline Ramajpura $\left(\mathbf{V}_{\mathbf{8}}\right)$ & 2.77 & 2.71 & & 2.74 & 13.85 & 13.68 & & 13.77 \\
\hline Babai $\left(V_{9}\right)$ & 3.69 & 3.57 & & 3.63 & 14.04 & 14.01 & & 14.03 \\
\hline \multirow[t]{2}{*}{ Mean } & 3.31 & 3.21 & & & 15.21 & 15.00 & & \\
\hline & F-test & S.Ed $( \pm)$ & C.D & at 0.05 & F-test & S.Ed $( \pm)$ & C.D & D. at $0.05 \%$ \\
\hline Due to depth & $\mathrm{S}$ & 0.08 & 0.00 & 004 & S & 0.15 & 0.01 & \\
\hline Due to site & S & 1.1 & $\begin{array}{l}0.00 \\
005\end{array}$ & 00000000 & S & 1.31 & 0.00 & 0000002 \\
\hline
\end{tabular}




\section{Available phosphorus}

In soil depth the highest mean available phosphorus was found in $0-15 \mathrm{~cm}(11.73 \mathrm{~kg}$ $\mathrm{ha}^{-1}$ ) which is significantly higher than $15-30$ $\mathrm{cm}\left(10.83 \mathrm{~kg} \mathrm{ha}^{-1}\right)$. In villages the maximum mean available phosphorus was found at Gambhira $\left(\mathrm{V}_{2}\right)\left(13.89 \mathrm{~kg} \mathrm{ha}^{-1}\right)$ and minimum mean available phosphorus was found in Kashipura $\left(\mathrm{V}_{6}\right)\left(10.29 \mathrm{~kg} \mathrm{ha}^{-1}\right)$. The available $\mathrm{P}$ varied from 9.96 to $14.98 \mathrm{~kg} \mathrm{ha}^{-1}$ in different depths and villages, which is low to medium content of phosphorus in soil. The highest $\mathrm{P}$ content was observed in the surface horizons and decreased with depth. Similar results were reported by Meena et al., (2010) (Table 4).

\section{Available potassium}

In soil depth the highest mean available potassium was found in $0-15 \mathrm{~cm}(462.91 \mathrm{~kg}$ $\mathrm{ha}^{-1}$ ) which is significantly higher than 15-30 $\mathrm{cm}\left(454.11 \mathrm{~kg} \mathrm{ha}^{-1}\right)$. In villages the maximum mean available potassium was found at Karwar $\left(\mathrm{V}_{4}\right)\left(729.25 \mathrm{~kg} \mathrm{ha}^{-1}\right)$ and minimum mean available potassium was found in Manpura $\left(\mathrm{V}_{3}\right)\left(381.5 \mathrm{~kg} \mathrm{ha}^{-1}\right)$. The available potassium in soil varied in high range (319 to $736.5 \mathrm{~kg} \mathrm{ha}^{-1}$ ) (Table 5).

The highest $\mathrm{K}$ content was observed in the surface horizons and showed more or less decreasing trend with depth. This might be attribute to more intense weathering, release of liable $\mathrm{K}$ from organic residues, application of $\mathrm{K}$ fertilizers and upward translocation of $\mathrm{K}$ from lower depths along with capillary rise of ground water. Similar results were reported by Urmila et al., (2018) and Sharma and Chaudhary (2017).

\section{Exchangeable calcium}

In soil depth the highest mean exchangeable calcium was found in $0-15 \mathrm{~cm}(6.29 \mathrm{Cmol}$ $\left(\mathrm{p}^{+}\right) \mathrm{kg}^{-1}$ ) which is significantly higher than
$15-30 \mathrm{~cm}\left(5.8 \mathrm{Cmol}\left(\mathrm{p}^{+}\right) \mathrm{kg}^{-1}\right)$. In villages the maximum mean exchangeable calcium was found at Mani $\left(\mathrm{V}_{5}\right)\left(9.08 \mathrm{Cmol}\left(\mathrm{p}^{+}\right) \mathrm{kg}^{-1}\right)$ and minimum mean exchangeable calcium was found in Karwar $\left(\mathrm{V}_{4}\right)\left(3.55 \mathrm{Cmol}\left(\mathrm{p}^{+}\right) \mathrm{kg}^{-1}\right)$. The calcium content decreases with increase in depth. Similar results were reported by Athokpam et al., (2010).

\section{Exchangeable magnesium}

In soil depth the highest mean exchangeable magnesium was found in $0-15 \mathrm{~cm}(3.31 \mathrm{Cmol}$ $\left.\left(\mathrm{p}^{+}\right) \mathrm{kg}^{-1}\right)$ which is significantly higher than $15-30 \mathrm{~cm}\left(3.21 \mathrm{Cmol}\left(\mathrm{p}^{+}\right) \mathrm{kg}^{-1}\right)$. In villages the maximum mean exchangeable magnesium was found at Karwar $\left(\mathrm{V}_{4}\right)\left(5.25 \mathrm{Cmol}\left(\mathrm{p}^{+}\right)\right.$ $\mathrm{kg}^{-1}$ ) and minimum mean exchangeable magnesium was found in Kashpuriya $\left(\mathrm{V}_{1}\right)$ $\left(1.56 \mathrm{Cmol}\left(\mathrm{p}^{+}\right) \mathrm{kg}^{-1}\right)$. The magnesium content decreases with increase in depth. Similar results were reported by Mehta et al., (2012) and Gill et al., (2012).

\section{Available sulphur}

In soil depth the highest mean available sulphur was found in $0-15 \mathrm{~cm}(15.21 \mathrm{ppm})$ which is significantly higher than $15-30 \mathrm{~cm}$ $(15.00 \mathrm{ppm})$. In villages the maximum mean available sulphur was found at Mani $\left(\mathrm{V}_{5}\right)$ $(17.26 \mathrm{ppm})$ and minimum mean available sulphur was found in Jaini was $\left(\mathrm{V}_{7}\right)(13.42$ $\mathrm{ppm})$. The available sulphur in soil varied in medium range (13.28 to $17.32 \mathrm{ppm}$ ).Similar results were reported by Urmila et al., (2018) (Table 6).

It is concluded that soil $\mathrm{pH}$ was neutral to slightly alkaline in reaction with EC mostly below $<1.0 \mathrm{dS} \mathrm{m}^{-1}$ for collected soil samples. The organic carbon, nitrogen and phosphorus content of these soils were found to be low to medium. Potassium was in high range. Calcium and magnesium were found to be adequate. 
The available sulphur in soil was recorded in medium range. Soybean, paddy, maize, sorghum, black gram and green gram are the main Kharif crops whereas wheat, mustard, barley and gram are the major Rabi crops of the district.

We concluded that there is a need to pay greater attention in the role of macronutrient enhancement in the soil for good soil health and soil quality and proper nutrition of plants so as to attain optimum economic yield. These observed spatial variability used in further fertilizer recommendation and input management based on requirement of crop plants. The adoption of organic farming will be essential step for maintaining soil health and soil quality.

\section{Acknowledgements}

I am grateful for ever-inspiring guidance, constant encouragement and scholarly comments and constructive suggestions throughout the course of my studies and investigation, from, head of the department and staff, Department of Soil Science and Agricultural Chemistry, Sam Higginbottom University of Agriculture, Technology and Sciences, Prayagraj, Uttar Pradesh.

\section{References}

Athokpam, Herojit Singh, Singh, R.K. Umakanta, Chongtham, Nandini, Singh, R.K. Kumarjit and Singh, N. Gopimohan (2010) Forms of potassium and their relationship with physicochemical properties of acidic soils in Manipur State. Agropedology, 20(2), 189-193.

Anderson, T. (2003) Microbial ecophysiological indicators to assess soil quality. Agriculture Ecosystems and Environment, 98, 285-293.
Bastida, F.ZA, Hernandez, H. and Garcia, C. (2008) Past, present and future of soil quality indices. A biological perspective. Geoderma, 147, 159-171.

Cheng, K.L. and Bray, R.H. (1951) Determination of Calcium and Magnesium in soil and plant material. Soil Sci., 72: 449-458.

Chesnin, L. and Yien, C.H. (1950) Turbidimetric determination of available sulphates. Soil Sci. Soc. Amer. Proc. 15: 149-151.

Das, D.K. (2015) Introductory soil science ( $4^{\text {th }}$ ed.). Kalyani Publishers, New Delhi.

Dadhwal, K.S., Mandal, D., Srimali, S.S., Dhyani, S.K., Mohan, S.C. and Raizada, A. (2011) Landscape-scale soil quality assessment under different land use systems in north-western hilly region. Ind. J. Soil Cons., 39(2): 128-135.

Doran, J.W. and Parkin, T.B. (1994) Defining and Assessing Soil Quality. in: Defining Soil Quality for a Sustainable Environment, (Eds.) J.W. Doran, D.C. Coleman, D.F. Bezdicek, B.A. Stewart, SSSA. Special Publication no. 35, Madison, WI, pp. 3-21.

District Profile - Krishi Vigyan Kendra, Bundi.

Dengiz, O. and Saglam, M. (2012) Determination of land productivity index based on parametric approach using GIS technique. Eura. J. Soil Sci., 1: 51-57.

District Factbook (2019) Rajasthan District Factbook Bundi District. Key Socioeconomic Data of Bundi District, Rajasthan.

Gill, R.S., Kanthaliya, P.C. and Giri, J.D. (2012) Characterization and classification of soils of Phalasia block of Udaipur district, Rajasthan. Agropedology, 22(1), 61-65.

Jackson, M.L. (1958) Soil Chemical Analysis. Prentice Hall of India. Private Ltd., New Delhi (1973). 
Kumar, A., Mishra, V.N., Srivastav, L.K. and Banwasi, R. (2014) Evaluation of soil fertility status of available major nutrients $(\mathrm{N}, \mathrm{P} \& \mathrm{~K})$ and micro nutrients (Fe, $\mathrm{Mn}, \mathrm{Cu} \& \mathrm{Zn}$ ) in Vertisols of Kabeerdham district of Chhattisgarh, India. International Journal of Interdisciplinary and Multidisciplinary Studies, 1(10): 72-79.

Kumar, M., Yadav, S.R. and Gulati, I.J. (2017) Evaluation of soil status in Sriganganagar district of Rajasthan. International Journal of Chemical Studies, 5(4), 776-780.

Karlen, D.L., Andrews, S.S. and Doran, J.W. (2001) Soil quality: Current concepts and applications. Advances in Agronomy, (74), 1-40.

Letey, J., Sojka, R.E., Upchurch, D.R., Cassel, D.K., Olson, K.R., Payne, W.A., Petrie, S.E., Price, G.H., Reginato, R.J., Scott, H.D., Smethurst, P.J. and Triplett, G.B. (2003) Deficiencies in the soil quality concept and its application. Journal of Soil and Water Conservation, 58(4), 180-187

Larson, W.E. and Pierce, F.J. (1991) Conservation and enhancement of soil quality. in: Evaluation for sustainable land management in the developing world. IBSRAM proceedings, No. 12 Vol. 2, Technical papers. Bangkok, Thailand, pp. 175-203.

Mader, P., Fliessbach, A., Dubois, D., Gunst, L., Fried, P. and Niggli, U. (2002) Soil fertility and biodiversity in organic farming. Science, 296(5573), 16941697.

Mehta, K.M., Shankaranarayana, H.S. and Jaisinghani, C.J. (2012) Study of Pedo Genesis of soils of Bundi district (Rajasthan). Soil Science and Plant Nutrition, 8:5, 32-38.

Meena, H.B., Giri, J.D. and Mishra, H.K. (2010) Nutrient availability in soils as affected by physiography in Chittorgarh district, Rajasthan. Agropedology, 20(1), 85-87.

Moebius-Clune, B.N., Moebius-Clune, D.J., Gugino, B.K., Idowu, O.J., Schindelbeck, R.R., Ristow, A.J., Van Es, H.M., Thies, J.E., Shayler, H.A., McBride, M.B., Wolfe, D.W. and Abawi, G.S. (2016) Comprehensive assessment of soil health. The Cornell framework manual, Edition 3.0. Third Edition. Ed. Cornell University, Geneva, NY.

Maheshwari, Rohini and Sharma, Indu Rani (2013) Soil Status in Relation to Blast Disease in Bundi District of Rajasthan, INDIA. International Journal of Pure \& Applied Bioscience, 1(1): 13-19.

Olsen, S.R., Cole, C.V., Watnahe, F.S. and Dean, L.A. (1954) Estimation of available phosphorus in soils by extraction with sodium bicarbonate U.S. Deptt. Agr. Circ., 939.

Rusch, H.P. (1985) Bodenfruchtbarkeit: eine Studiebiologischen Denkens. Karl F. Haug Verlag, Heidelberg.

Ram, R.L., Sharma, P.K., Jha, P., Das, S.N. and Ahmed, N. (2010) Characterization and classification of soils of Nagarjunasagar catchment in Shorapur taluk of Gulbarga district, Karnatakastate. Agropedology, 20(2), 112-123.

Sharma, Kirti Mohan and Chaudhary, Hardev Singh (2017)Physico Chemical Analysis of Soils of Digod Tehsil, Kota and Their Statistical Interpretation. International Journal of Science and Research, 2319-7064.

Singh, S.K., Kumar, Mahesh, Sharma, B.K. and Tarafdar, J.C. (2007) Depletion of Organic carbon, phosphorus and potassium stock under pearl millet based cropping sequence in arid environment of India. Arid land Research and Management, 21, 119131. 
Sojka, R.E. and Upchurch, D.R. (1999) Reservations regarding the soil quality concept. Soil Science Society of America Journal, 63(5), 1039-1054.

Sojka, R.E., Upchurch, D.R. and Borlaug, N.E. (2003) Quality soil management or soil quality soil management: Performance versus semantics. in: Advances in Agronomy, Vol 79, (Ed.) D.L. Sparks, Vol 79, pp. 1-68.

Subbiah, B.V. and C.L., Asija (1956) A rapid procedure for the estimation of available nitrogen in soils. Current Sci., 25: 259-260.

Toth, S.J. and A.L., Prince (1949) Estimation of cation exchange capacity and exchangeable $\mathrm{Ca}, \mathrm{K}$ and $\mathrm{Na}$ content of soil by flame photometer technique. Soil Sci.,67: 439-445.
Urmila, Purohit, H.S., Singh, D., Meena, S.C., Jain, H.K., Kumar, Amit and Verma, S.N. (2018) Effect of tillage on physicochemical indices of soil in maize based cropping sequence of southern Rajasthan. International Journal of Chemical Studies, 6(4): 2490-2493.

Warkentin, B.P. (1995) The changing concept of soil quality. Journal of Soil and Water Conservation, 50(3), 226-228.

Walkley, A. (1947) Critical examination of rapid method for determining organic carbon in soils, effect of variation in digestion conditions and of inorganic soil constituents, Soli Sci., 632: 251.

Wilcox, L.V. (1950) Electrical conductivity, Amer. Water Works Assoc. J. 42: 775776.

\section{How to cite this article:}

Banwari Lal Meena, Tarence Thomas and Narendra Swaroop. 2020. Evaluation of Soil Health and Soil Quality Analysis of Different Blocks of Bundi District, Rajasthan, India. Int.J.Curr.Microbiol.App.Sci. 9(08): 2040-2050. doi: https://doi.org/10.20546/ijcmas.2020.908.231 